\title{
Improved Response to Water Shortage: A Discrete Choice Experiment Study in Langata Sub County, Nairobi City-Kenya
}

\author{
E. A. Ochungo ${ }^{1 *}$, G. O. Ouma ${ }^{2}$, J. P. O. Obiero ${ }^{3}$, N. A. Odero 4 \\ ${ }^{1}$ Institute for Climate Change and Adaptation (ICCA), University of Nairobi, Nairobi, Kenya \\ ${ }^{2}$ Department of Meteorology, University of Nairobi, Nairobi, Kenya \\ ${ }^{3}$ Environmental and Biosytems Engineering, School of Engineering, University of Nairobi, Nairobi, Kenya \\ ${ }^{4}$ Department of Electrical and Electronics Engineering, Machakos University, Machakos, Kenya \\ Email: *elishakech1@gmail.com
}

How to cite this paper: Ochungo, E.A. Ouma, G.O., Obiero, J.P.O. and Odero, N.A. (2019) Improved Response to Water Shortage: A Discrete Choice Experiment Study in Langata Sub County, Nairobi City-Kenya. Journal of Water Resource and Protection, 11, 1161-1187.

https://doi.org/10.4236/jwarp.2019.119068

Received: August 20, 2019

Accepted: September 17, 2019

Published: September 20, 2019

Copyright (c) 2019 by author(s) and Scientific Research Publishing Inc. This work is licensed under the Creative Commons Attribution International License (CC BY 4.0).

http://creativecommons.org/licenses/by/4.0/

\begin{abstract}
This study aimed at identifying the most preferred water quality tracking system (WQTS) for adoption and the determining factors for the same among the Langata sub County households in Nairobi city, Kenya. Perrenial municipal water shortage in this neighborhood has forced the residents to depend on vended water supplication but whose quality is not possible to verify at the moment. Accordingly, a mobile phone quality tracing application running on blockchain technology platform was developed to fill the gap of provenance tracking. A non-market discrete choice experiments (DCEs) model was deployed in which four-option attribute bundles; with one being the "status quo" choice were presented to each of the 382 randomly sampled respondents from the five wards within the area. Results indicated that Option 2; the communally managed WQTS emerged as the most preferred choice at $53.9 \%$. Secondly, the male factor was identified as the major determinant to this decision. In conclusion, the study proposes for the installation of this new WQTS which will trigger a $12 \%$ adjustment of the average household's monthly water bill. In addition, this paper recommends for a city-wide assessment of residents' willingness to pay (WTP) for this WQTS, which it deems as an improved response to water shortage problem. Finally, the study contributes to the application of DCEs model in technology adoption literature.
\end{abstract}

\section{Keywords}

Water, Alternatives, Doubt, Trust, Quality Tracking System, Communal Action 


\section{Introduction}

Studies on response to water shortage conditions in urban areas continue to attract a lot of global interest. Pioneer investigators have focused more on how to increase water supply flows in municipal taps to narrow the ever widening demand-supply gaps. Today however, drought risks have complicated this incremental approach [1] [2]. Most water supply service improvement schemes based on infrastructure expansion quickly become obsolete due to multiple convoluting stressors in the local scenes [3]. Consequently; the dependent households do turn to alternative water sources [4]. In the developed world, technologies such as desalination and waste water recycling do offer credible alternatives according to [5] [6] [7] [8]. In the poor nations on the other hand, more than 700 million people are known to rely on informal water market when the municipal supplies fail, but whose quality is not trusted [9] [10] and [11].

Langata sub County in Nairobi city-Kenya, presents a stark example of a place where water consumers face a perennial water shortage challenge [12]. Here, water vendors do step in to fill the gap when Nairobi City Water and Sewerage Company (NCW \& SC) service is down [13]. But, the households are forced to use quality enhancing measures due to negative perception they hold regarding the quality of the vendor supplied water [14] [15]. The persistent distrust on vendor water quality is because, currently, the informal water market is unregulated.

And so; there is no system to monitor the latter's quality. Surprisingly, even the municipal water systems traditionally also just have their quality monitoring on centrally managed frameworks [16]. This means that the informal water consumers have no way to verify water quality in near real time before use [17]. For this reason, this paper strongly argues for the informal water markets to have a quality monitoring system as earlier suggested by [18]. It is expected that upon having such a system in place, the informal water market alternatives may serve as improved (credible) sources of water to cope with water shortage challenges bedeviling urban communities [19] [20]. The proposed real time quality tracking system is supposed to be mounted on a diffused technology in common use by households [21]-[27]. One of the most ubiquitous devices in use these days is the mobile phone handset gargets which can help in quality monitoring of water from source to the consumers' door steps [28]-[34].

The study assumes that the perceptive mind of a consumer can build trust on the informal market's water source once he or she is able to track and verify its quality [35]. The acquired trust is expected to make such a consumer to abandon the home-based water quality improvement measures thereby relieving him or her the agony of having to spend so much every day [36] [37]. Subsequently, the out of pocket expenses money saved through such a move may be invested in other family needs, which will, among other benefits, further improve the overall wellbeing of individual households [38] [39] [40]. Buoyed by this reasoning, the study developed a mobile phone application prototype for tracking the informal 
water quality. The system is to be operated on an internet run blockchain technology platform which is considered here as a low cost approach [41] [42] [43]. The study is to use stated preference method to realize the intended aspiration.

\subsection{Theory of Stated Preference Models}

In environmental valuation, it is always possible to estimate how much an individual is willing to pay on average for a given "good" or "service". In this paper a water quality tracking system (WQTS) was presented to decision makers as a set of choices of a product with varying attributes with different price tags [44] [45] [46]. Although WQTS are market 'goods', fixing the estimated price that individuals are willing to pay for their future installations is only possible using an hypothetical market [47] [48]. The usual way in market interventions is to promote the adoption through consumer subsidies and or mandated adoption [49]. The most important idea in the process is to identify the gap between the value individuals are willing to pay (WTP) and the actual market price [50]. This is the reason as to why stated preference models are commonly described as (DCEs), that is; discrete choice experiments [51]. DCEs are applied in environmental protection studies as they are flexible in assessing customer preferences in hypothetical conditions according to [52] [53] [54].

Discrete choice experiments (DCEs) are actually an attribute trade-off method given that it presents a series of scenarios and ask respondents to state (through choosing) the preferred scenario that describes a "good" or "service" using pre-defined attributes and levels [55] [56]. It is used to value individual attributes that make up "good" or "service" and it allows for the estimation of a trade-off between different attributes [57] [58]. A trade-off is defined as a balance of opportunity costs which maximizes utility [59]. Attribute based methods are grounded in random utility theory which suggests that an individual consumer has a unique value for particular features of goods or services rather than the product as a whole in a heterogeneous manner. Representing a choice task as used in DCEs is arguably more natural because they more closely represent decisions made by humans in everyday life. DCEs method also allows for the use of pictorial representations of choice sets to aid in cognitive reasoning [60].

Further, historical evidence suggests that DCEs are less burdensome and possibly do produce more reliable results. For that reason, in this study DCEs were used to determine whether households in Langata are WTP for WQTS. All attribute-based valuation methods, including DCEs, are based on theories developed by Lancaster in his 1966 paper: "A New Approach to Consumer Theory". This study uses the traditional theory of consumerism that "goods are goods" [61] based on three fundamental underpinning assumptions as elucidated in random utility theory by Lancaster; the latter being the building block of all stated preference studies. These include; 1) consumers value the attributes that a good possesses, rather than the good itself; 2) goods are made up of many attributes which are not necessarily unique to that good; and 3) two goods together may possess different attributes from those when they are separate. 
DCEs method incorporates these three threads of thoughts through the development of alternative profiles, choice sets and interactions between attributes, respectively. The Random Utility Theory (RUM) explains that the way individuals choose between the alternatives presented in a DCE can be explained using probabilistic choice theory. The choice behavior by individuals can be understood from either of these two perspectives: 1) decisions are random in nature and utility is always deterministic; and 2) decisions are deterministic and utility is random and that 'actual' behavior cannot be modeled. In the first perspective, the individual can be assumed to choose on impulse as influenced by psychological factors [62]. In contrast, the second perspective regards individuals as utility maximizers, but there is a random component to this maximization as was discussed by Thurstone in 1927 [63]. The second perspective, suggests that decisions are not made randomly but rather utility has a random component.

The random utility models used to explain the uncertainty around predicting consumer and respondent choices are underpinned by Random Utility Theory (RUT). RUT was originally investigated by [63] who looked at the derivation of satisfaction, or utility, through a "Law of Comparative Judgment" with a psychological perspective. The theory was developed substantially in the 1970s with econometric input from the 2000 Nobel Prize Winner, Daniel McFadden [64] [65]. RUT provides a deterministic-decision framework which is not trying to explain irrational behavior, but model the researcher's lack of information. The lack of information results in an error which could be due to measurement errors or latent attributes that influence choice or heterogeneity in preferences, that is; the unobserved differences in taste [66]. Therefore, the psychological factors which influence choice are incorporated into this random component of utility [67]. RUT is based on the simple axiom that it is not possible to observe the 'actual' utility function; however, it is possible to infer what is affecting utility from deterministic decisions being made.

\subsection{Related Work}

Unfortunately, it was noted that significantly, less work seems to have been done on citizens' reaction to a technology driven water quality verification system. The small body of literature that does exist situate drinking water quality verification role on governments which are meant to create legal and institutional frameworks to ensure delivery of safe and reliable drinking water [68]. And on governments' subsidiary agency arms commonly referred to as water service providers, which as per service level agreement provisions, are to develop and implement drinking water safety plans to facilitate water quality monitoring [69]. Talk of wireless sensor node-based water quality tracker [70] [71] [72] [73] [74], GPRS-based remote water quality analysis [75] or any other form of crowd sourcing for water quality monitoring [76] [77] [78]; the interest continues to grow especially in the face of drought and water contamination challenges confronting our cities today [79].

There are however, two perspectives at play in this continuum; informal water 
alternatives and their quality verification capability. The alternatives take such forms as: rainwater, treated grey water and groundwater which are close sources of water to the point of use such as within property boundary of a typical urban home [80]. The informal water market alternatives supplement municipal water supplies through vendor delivery in push carts and/or tankers [81]. On the other hand, drinking water quality aspect is taken as a foundational matter that affects all stakeholders in water provision services' landscape [82] [83] [84]. Accordingly, all water service providers are expected to monitor the quality of water they supply; a requirement which the informal water market players (vendors) are least prepared to comply with [85]. These water vendors are only in a rent seeking sort of festival, but remain unaccountable to the resulting negative implications on their customers [86] [87]. In order to transform the informal water market enterprise, the consumers ought to make a choice using mobile phone application run quality tracking system [88]. Since such a system has no shelf price; a non-market valuation method was used to market the bundle of choice options as earlier suggested by scholars such as [89] [90] [91] [92].

The application of DCEs models has been witnessed in many studies, for example; in valuing of tap water quality improvement [93], assessing willingness to adapting to less water in urban Australia [94], assessing social benefits of improved water supply service [95] and in weighing public perception on desalinated water [6]. Further DCEs models have assisted in determining factors for adoption of safe water technologies [3], use of household level chlorination products in Kenya [96] and assessing end user preference for water treatment technologies in rural Kenya [97]. Additionally, it has been used to assess welfare effect of improved water quality [98], to estimate WTP for watershed protection by domestic water users in Tugueragaro City, Philippines [99], the valuation of groundwater protection in Denmark [100] and to assess the adoption of water efficient equipment by households [90]. One notable feature in all these studies is the heterogeneity of individuals in making decisions on a choice based on the available attributes.

Despite the fact that WQTS is a market good, there is lack of market data to reliably link socio-economic and attitudinal information to the (WQTS) purchasing behavior as stated in previous similar work by [101]. As a result, in this study, stated preference choice experment (CE) was applied due to its rising popularity in water sector studies [102] [103] [104] [105]. This was to help determine whether households in Langata are willing to pay (WTP) for four different types of WQTS with the existing arrangement of water access being a baseline as "status quo" choice; Individual WQTS Figure 1, Communal WQTS where houses are connected to water source via smart meters see Figure 2 \& Figure 3, Combination of Individual and Communal WQTS Figure 4. Option four is the existing set up, Figure 5 \& Figure 6 . The design of choices was based on the advise sought from studies by [106] [107] [108] [109]. It should be noted that the proto-type of the WQTS that was marketed in this study has been presented in a separate paper. 
**Individuals using platform in isolation**

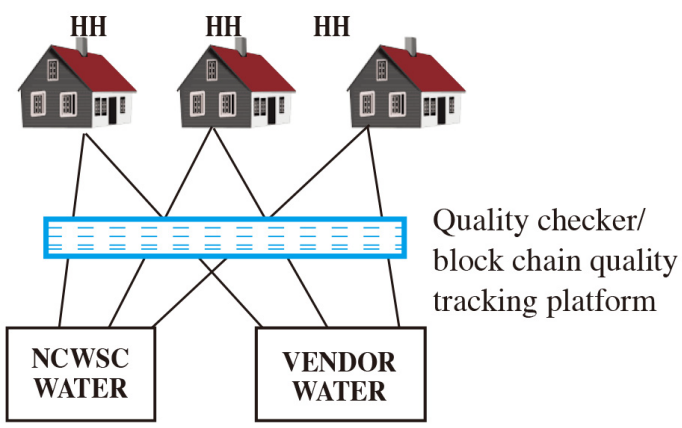

Figure 1. Individual WQTS installation.

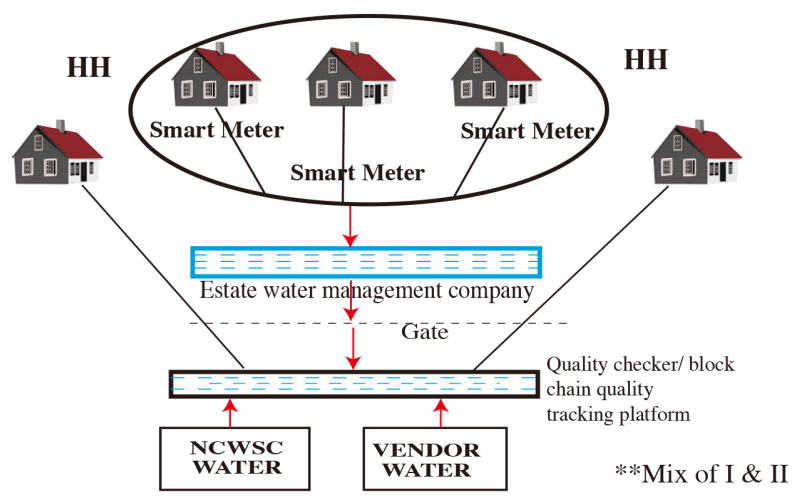

Figure 2. Communal WQTS installation.

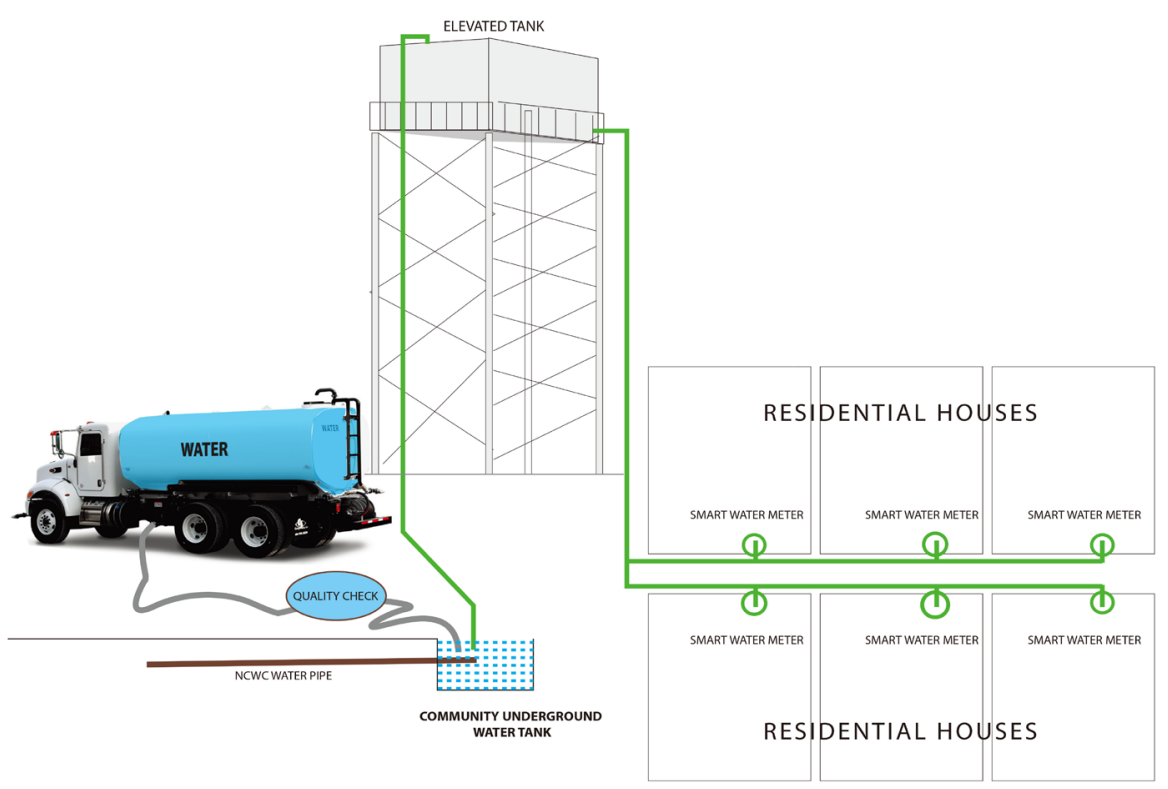

Figure 3. Communal WQTS installation proto-type.

The amount of money that an individual is willing to pay (WTP) is used to reflect his or her preference for one system over the other as was proposed by [110] [111]. In this study, the payment is presented as a percentage adjustment to the current average household's monthly water bill, being a payment type as 


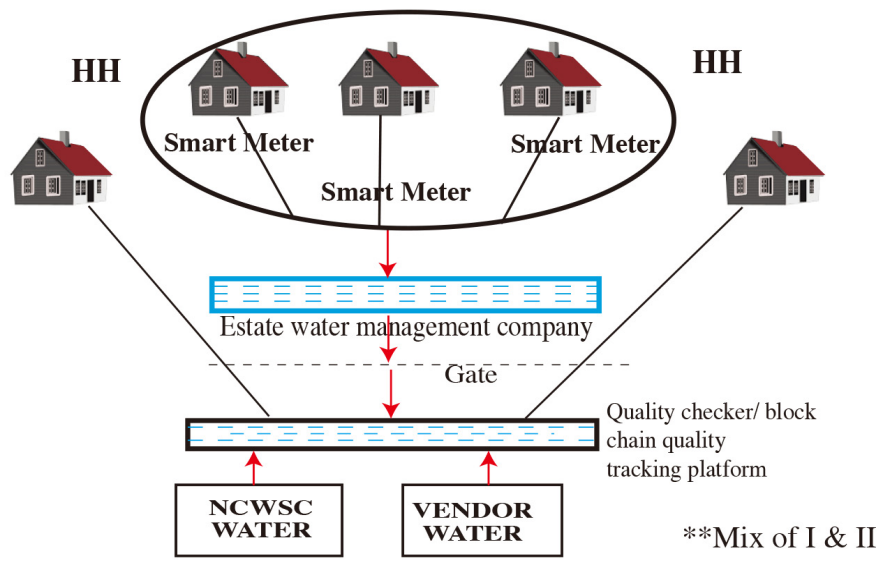

Figure 4. Individual and Communal WQTS installation.

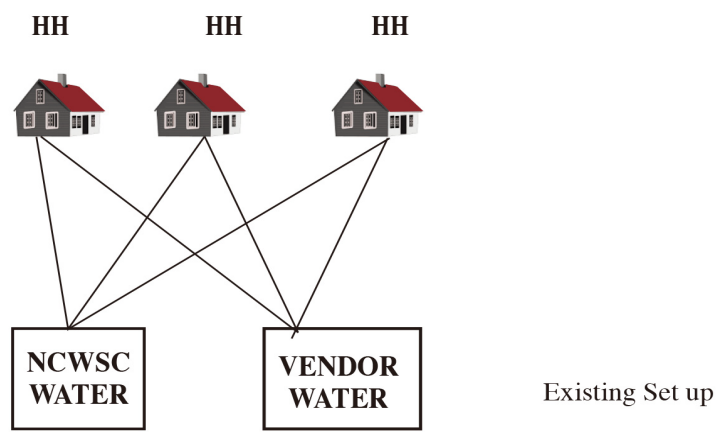

Figure 5. Existing status of household water access.

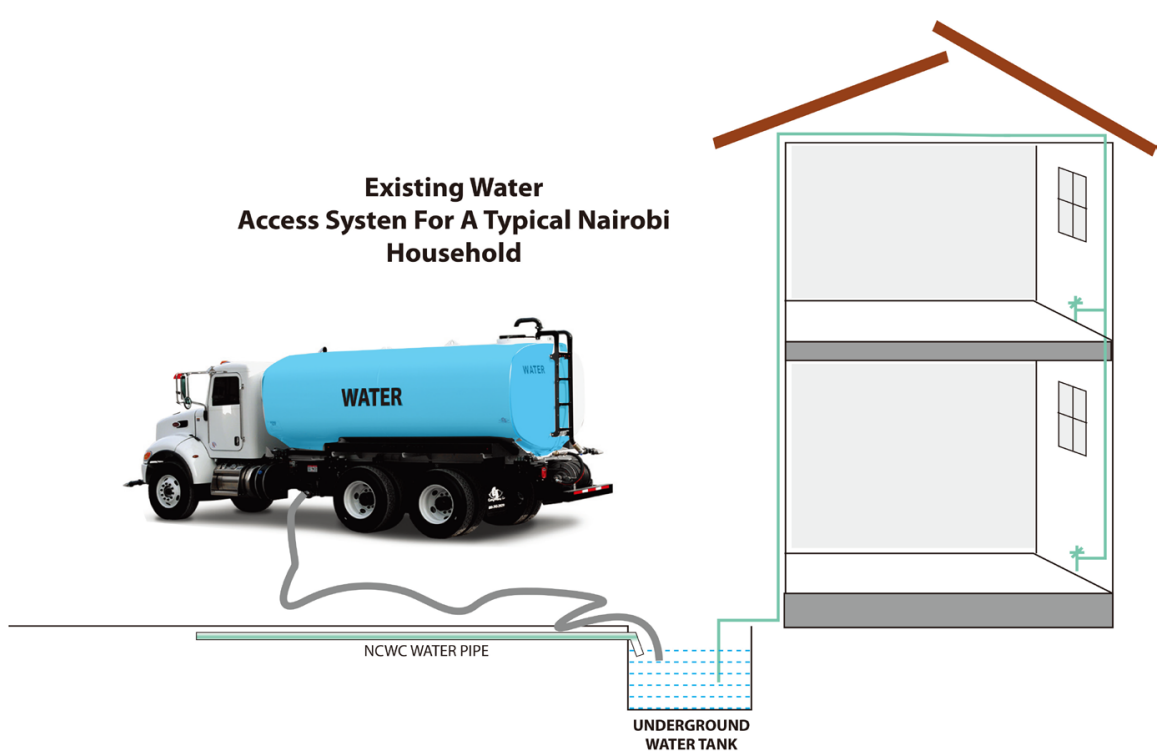

Figure 6. Impression of existing status of household water access.

discussed by [112]. And the investment of the new system is supposed to be undertaken by the utility company up front, so that the cost recovery is done through the tariff adjustment The real hidden reasons for the first three choices' attributes were mainly to; bring in equity policy in water access [95] [113] and to 
provide the much needed protection to the local groundwater environment [99] [100] [114]. The existing water shortage response types continue to overburden consumers in a number of ways. For example, the monthly expenditure on vendor water consumption is too high if the averting expenditure levels are taken into account [115]. Secondly, the craze in borehole drilling in Langata may trigger groundwater depletion risk in the not so distant future [116].

There are however, a number of ways to allow for the individual heterogeneities in DCEs models. The study took the approach of latent class model [117] Latent Class approach is hailed for allowing for the identification of a number of classes of respondents who may hold quite different preferences [118]. Within the constraint inherent in the number of classes identified, there are no limits on the distribution of preferences nonetheless, unlike the alternative approach of random parameter conditional logit models [119]. To the best of our knowledge, little if any, has been done to equip the households in such a manner. One of the fundamental pillars in water supply service industry is that change decisions require communal endorsements [120] [121] [122]. Accordingly, the study aim was to investigate the households' preference for a water quality tracking systems (WQTS) and the factors influencing the same. This study contributes in the application of DCEs model in the adoption of WQTS. The rest of the paper is organized thus; Section 2 presents method, Section 3 is results, Section 4 is discussion while Section 5 is conclusion.

\section{Method}

\subsection{Study Area}

Langata sub County is one of the 17 administrative units of Nairobi City County (NCC) with an estimated population of 176,314 people living in 52,656 households occupying an area of $196.80 \mathrm{~km}^{2}$. It is bounded to the North by Dagortti sub County, Kibra sub County, Starehe sub County, Embakasi sub County, Machakos Couty and to the South by Kajiado County. It is about $10 \mathrm{~km}$ to the South of Central Business District. It is located at approximately $1^{\circ} 22^{\prime} 0^{\prime \prime} \mathrm{S}$, $36^{\circ} 44^{\prime} 0 " \mathrm{E}$ and with a topographical height range from $1600 \mathrm{~m}$ to $1850 \mathrm{~m}$ above mean sea level. It enjoys a tolerable temperate tropical climate throughout the year. It has five wards, namely; Karen, Mugomoini, Nairob-West, South C and Nyayo High-Rise, see Figure 7.

The annual average rainfall ranges between $800-1200 \mathrm{~mm}$. There is a constant 12 hours of daylight. Average daily temperature ranges from $29^{\circ} \mathrm{C}$ in the dry season to $24^{\circ} \mathrm{C}$ throughout the year. The study area is serviced by a monopoly-enjoying Nairobi City Water and Sewerage Company Limited (NCW \& Co.Ltd) whose supply distribution is on rationing program. Accordingly, water vending business is booming as a complementary source of domestic water, which in this study are known as the alternatives. It is also important to note, that Langata has a predominantly mixed development with all categories of households; from the most affluent in Karen neighborhood to the low income 


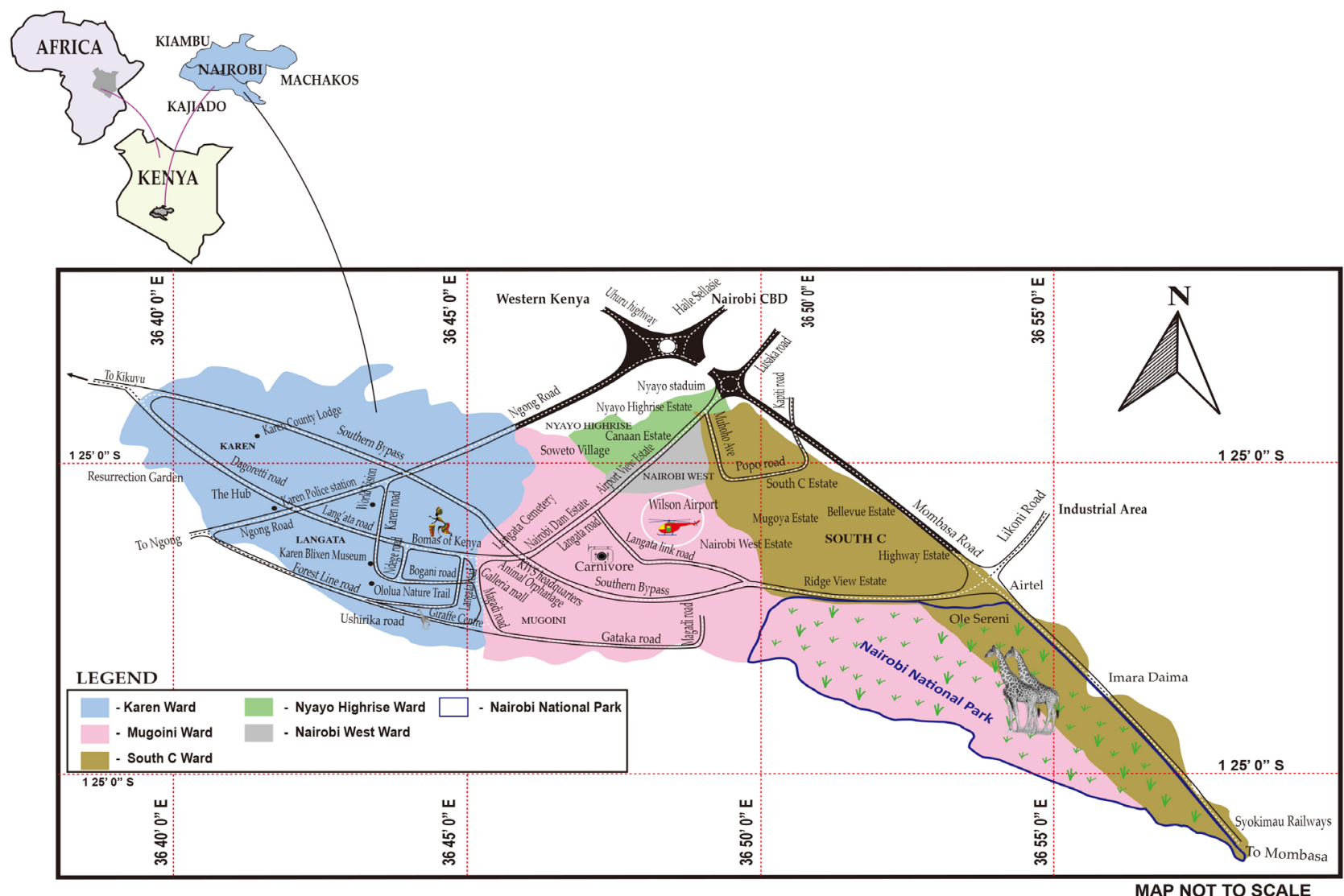

Figure 7. Location map.

groups sporadically spread within each ward. It prides itself to be the host of the famous Nairobi National Park. There are higher concentrations of private commercial boreholes in the area. It is important to note that for the purpose of this study, water vendors refer to all categories; tanker operators, cart pushers and other conveyance modes, all of which have no known quality monitoring mechanisms.

\subsection{Estimation of Preferences on a Conditional Logit Model}

A conditional logit model assumes that the utility for an individual (or a decision maker), $i$, has to make choice from a set of $J$ alternatives from which he/she derives a certain level of utility $U_{i j}$ expressed as;

$$
U_{i j}=V_{i j}+\varepsilon_{i j}
$$

where $\varepsilon_{i j}$ is unobservable unknown. Collectively, these assumptions are of extreme value type I often referred to as the independently and identically distributed (iid) conditions. While $V_{i j}$ is the representation of the portion of the utility with linear attributes.

$$
\text { Linearly } V_{i j}=\beta_{i k \times i j k}
$$

where $k$ is the attributes for $X_{i}$ alternative from $j$ alternatives and $\beta_{i k}$ is the

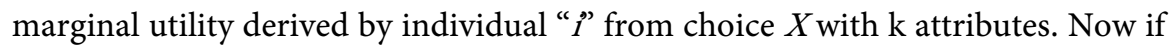


$y i=j>$ individual " $i$ " selects option $\mathrm{j}$ from available alternative 1 and 2 , then the probability of that individual " $i$ " selecting $j$ from a set of $N$ alternatives is expressed as;

$$
P(y i=J)=\frac{\exp \left(\lambda V_{i j}\right)}{\sum_{n=1}^{N} \exp \left(\lambda V_{i n}\right)}
$$

where $\lambda$ is the scale parameter given by random term $\lambda^{2}=\frac{\Pi^{2}}{6 d^{2}}$ related to $\beta$ which varies across groups. Should the parameter be same, conditional logit model can be used otherwise mixed logit models is applied. It is taken that choices may be similar in a class but may be different across classes (section of the group) and this is expressed as " $c$ ";

$$
P(y i=j / c)=\frac{\exp \left(\lambda \beta_{i k} X_{i j k}\right)}{\sum_{n=1}^{N} \exp \left(\lambda \beta_{c k} X_{i n k}\right)} .
$$

For an iterated bidding process, it is assumed that class behavior will remain constant within the tasks expressed by;

$$
P(y i=j / c)=\frac{\exp \left(\lambda \beta_{i k} X_{i j k t}\right)}{\sum_{n=1}^{N} \exp \left(\lambda \beta_{c k} X_{i n k t}\right)} .
$$

With increasing group or class diversity, the flexibility of the latent class increases and loses distributive restrictions of mixed logit models. But this reaches a statistical limit of a certain number of class identifiable in a sample, at this point, when " $c$ " approaches $N$ (respondents), then a specific focus of model becomes real beyond which the experimental design is incapacitated. If the probability of an individual " $i$ " within class " $c$ " from total classes " $C$ " is expressed as $S_{i c}$ then the unconditional chance of the same individual " $i$ " making a series of choices across $T$ choice sets is given by;

$$
P(y i)=\sum_{c=1}^{c} S_{i c} \prod P\left(y_{i t} / c\right) \text {. }
$$

Each choice by " $c$ " is assumed to be empirical with varying criteria being in use to identify number of classes. The functional form for the utility $\left(V_{i j}\right)$ for individual " $i$ " whose taste is alternative $j$ is expressed as;

$$
V_{i j}=\beta_{s} S Q_{j}+\sum \beta_{T} \text { TECH }_{i j}+\alpha_{p r} \text { PRICE }_{j}
$$

where $S Q$ is the Status Quo dummy variable and $T E C H_{i j}$ are the technology options for the water quality tracking system (WQTS) in alternative $j$ chosen by individual " $i$ ". PRICE $E_{j}$ is the proposed cost adjustment in percentage (\%) by utility company to implement the choices upon policy formulation. $\beta_{s}$ is coefficient of the status quo dummy variable, $\beta_{T}$ is the vector of marginal utility and $\alpha_{p r}$ is coefficient of price variable.

The willingness to pay (WTP) is expected to increase with the manner in which the water access system will be organized at the estate level to allow for the informal water quality tracking. The shift should at the same time act to 
protect the ground water environment from degradation. Each choice consisted of three options with alternative bundles of community water management system on WQTS, plus a fourth option which is the status quo $(S Q)$, or, "none of these" alternatives. In the utility algorithm, the $S Q$ dummy and its parameters contained "no-change" option that is unexplainable from the attributes of the alternatives and is related to individual's unique preference for change. The probability of individual membership to a class $S_{i c}$ is framed as a function of individual characteristics $\left(Z_{k i}\right)$ on a multinomial logit model (MNL) expressed as;

$$
S_{i c}=\frac{\exp \left(d_{c k} Z_{k i}\right)}{\sum_{j=1}^{c} \exp \left(d_{j z} Z_{i}\right)}
$$

The variation of class membership summation according to stated preference in choice should be equal to zero expressed as; $\sum_{j=0}^{c} d_{j z}=0$. The net-worth or maximum amount each respondent will be willing to pay for change as an attribute is a coefficient estimated under the mix logit model. And $S Q$ dummy is a motivation to avoid radical change promoting a win-win or trade-offs for long held beliefs. The value options as part-worth is expressed as;

$$
\text { Part }- \text { Worth }=\frac{-\beta_{S}+\beta_{T}}{\alpha_{p r}}
$$

It has been argued before in many studies that incorporating psychological factors such as behavioral attributes and beliefs in choice experiments helps in faster prediction of peoples' choices as was stated by [123].

In analyzing the constructs, factor analysis was used as a data reduction technique to come up with a composite variable to represent coping behavior expressed as;

$$
B E H A V_{i}=W_{1} X_{1 i}+W_{2} X_{2 i}+\cdots+W_{n} X_{n i}
$$

where $B E H A V_{i}$ is the estimated composite score for behavioral variable, $W_{n}$, are the factor score of regression weight and $X_{n i}$ are the observed score for each indicator.

\subsection{Survey Design}

Identifying the decision to be made is the most important stage of the study through definition of choice situation. In this study the design was preceded by establishing the list of gated communities within Langata. This was requested for from Kenya Alliance of Residents' Association (KARA). A total of 57 groupings were identified from the list issued in the month of January, 2019 just prior to the entry workshop event. Upon receipt, a survey tool was drafted. Then the group chairmen were contacted through their telephone contacts to establish the location of their offices where letters of invitation detailing the research objectives, authorization and request to attend first community workshop were delivered. The initial workshop was held on $20^{\text {th }}$ February, 2019 at YMCA hall in South C. 
The main objective of the meeting was threefold; one, introduction of research team to the community (familiarization), two, presentation of research objectives through the draft questionnaire for interrogation and three, notification of start of household surveys. The questionnaire was adjusted to incorporate input from the meeting. The final questionnaire had 19 questions spread in 4 sections to collect socio-demographic and water use information. Section 1, dealt with General Information; Date of survey, Name of respondent and Estate of residence. Section 2, dealt with Respondent's Information; Gender, Age, Number of years of stay in the estate and Education level choices; none (zero level education), primary level, secondary level, college level and university level.

Section 3 had five parts; A, B, C, D and E. In Part A; a future perception of water shortage was assessed based on a likert scale as per guide by [124]. The scale had five score values, namely; $1,2,3,4$, and 5 where value $1=$ Strongly Disagree that water shortage will worsen in the area and $5=$ Strongly agree that water shortage will worsen in the area. The intermediate values were in between those two extremes. Additionally in this section 3-Part A, the respondent was again provided with three boxes to score his/her monthly household's water bill; Water Company (Utility-U), Water vendor (Tanker-T) and Bottled water purchase (B). There was again another box to provide water vendor name, delivery type (cart or tanker) and contact.

In the information sheet, there was an important notice to the effect that, the survey targeted only household heads that are believed to be above 18 years of age. Section 3, Part B; dealt with scoring on a likert scale as A above on acceptance on community based sourcing of municipal and vendor water through a Blockchain enabled provenance tracking platform to facilitate water source quality verification. Part C; just as A above, asked the respondents to agree or disagree that, the shift in $\mathrm{B}$ above will partly solve the ongoing water shortage in the area. Part D; as C above sought to confirm that the ability to confirm informal water's quality before making a delivery order is likely to reduce water shortage stress in the study area. Part E; sought to confirm from the respondent using the same likert scale to confirm or disagree with the statement water shortages are inevitable; therefore, there is nothing we can do about it.

Section 4 dealt with vendor water-blockchain enabled quality tracking system installation options in four parts; a, b and d. Part b had two sub parts; (i) and (ii). In part (a), the respondent was given two choice "yes" and "no" and the question was, "does your estate/village/neighborhood experience water shortage?". In part (b), the respondent was asked to confirm using "yes" or "no" answers whether when the municipal water supply failed, he/she sourced from a vendor. In part (b) sub Section (i), the respondent was asked to answer using "yes" or "no" choices whether, after sourcing from a vendor, she/he improved water quality by any means. In part (b) sub Section (ii), in case the answer in part (b) above sub Section (i) is "no", the respondent was asked to confirm using "yes" or "no" choices whether, he/she instead depended on bottled water on a dispenser for drinking purposes. 
Finally in Part (c), the respondent was to state his/her agreement using "yes" or "no" to confirm the quality of vendor/municipal water on a blockchain provenance tracking system with a caveat caution that the answer given was to affect his/her response to part (d). Part (d) involved selection of only one option choice from a set of four option choices of quality tracking platform. Each had a likely effect on future monthly household water bill. Option (I), was based on individual household tracking platform with $15 \%$ municipal water tariff adjustment, Option (II), was a gated community water quality tracking and sourcing through estate water management company with a $12 \%$ effect on current municipal household monthly water bill, Option (III) was a blend of (I) and (II) as above described and finally, Option (IV) was no action (Status Quo). Each option was diagrammatically presented. Further; the survey team had a translated questionnaire in "Kiswahili language" for any respondent who had a challenge with the "English version". For this paper, Part 3 (A) of the questionnaire has been left out in the analysis.

\subsection{Sampling and Participant Recruitment}

The study used simple random sampling method; in which each unit included in the sample has equal chance of inclusion in the sample. This technique provides the unbiased and better estimate of the parameters as the population was assumed to be homogeneous [125]. The fact that the study area is well planned made distribution of questionnaires easy. To ensure randomness and wide coverage in the sampling process, the study followed the 57 gated communities spread within the five wards of Langata sub County. Circular systematic sampling was used in this study to select a household within a gated community.

Systematic sampling is a probability sample selection method in which the sample is obtained by selecting every $k^{\text {th }}$ element of the population, where $k=$ $N / n$ where $N$ is population and $\mathrm{n}$ is the sample size. The first sampling unit is selected randomly within the first $\mathrm{k}$ units of the list. For instance, if $k=10$, then a random number between 1 and 10 is selected first. Suppose the selected random number is 8 . Then starting with the 8th house in the list of households in the gated community, every 10 th house $\left(8\right.$ th, 18 th, $\left.28^{\text {th }} \ldots\right)$ is sampled until the desired sample size is reached. We deployed the [126] formula in determining sample size as expression in Equation (11) below;

$$
n=\frac{\left[\frac{P[1-P]}{\frac{A^{2}}{Z^{2}}+\frac{P[1-P]}{N}}\right]}{R}
$$

the population (52,656 households in our case, see section 2.1 above) $P=$ estimated variance in population, as a decimal: (0.5 for 50-50,) $A=$ Precision desired, expressed as a decimal (i.e. $0.05 \%$ for $5 \%$ ) $Z=$ Based on confidence level: 1.96 for $95 \%$ confidence, $R=$ Estimated Response rate, as a decimal, in our case $100 \%$ which is 1 . 


\subsection{Household Survey}

The estimated target sample size is 382 households, computed from Equation (11) above. A total of 382 questionnaires were eventually distributed to 57 gated communities. The questionnaires were distributed to; Karen ward with 9467 households which received 69 copies into its 14 zones with 13 zones along major roads receiving 5 copies each and the last 1 zone receiving 4 copies of questionnaire. For South $\mathrm{C}$ ward with 13,637 households, 99 copies were distributed into its 12 gated communities with 11 receiving 8 copies each and 1 community receiving 11 copies. In Mugomoini ward with 12,867 households, 22 communities received 4 copies each and 1 community received 5 copies of questionnaire, making a total of 93. For Nairobi West ward with 8311 households, each of its 4 gated communities received 15 copies each making a total of 60 . Lastly, for Nyayo Highrise ward with 8374 households, 3 of its gated communities received 15 copies each and 1 received 16 copies making a total of 61 .

Questionnaires were administered to adult members of the family (household heads) by two researchers; male and female, who explained every detail to each of the respondents. For the literate class, the researchers left the questionnaires with the respondents for a minimum of three days to allow adequate time for filling the questionnaires. In some cases, repeated visits were made before the questionnaires could be retrieved. For the illiterate and semi literate group, the researchers guided the respondents through the filling process, using Kiswahili language version of the questionnaire. In some other cases, the researchers had to fill the questionnaires in accordance with responses from respondents. Note that the household survey had two objectives; one, to assess the implication of water vending in terms of cost burden to the households. And, two, to assess the determinants for adoption of new coping measure. This paper presents only the results of first objective.

\subsection{Statistical Analysis Method}

Simple descriptive statistics was used to pick out most important information from the household survey data. MS Excel and IBM SPSS Statistics Version 25 tools were deployed.

\section{Results}

\subsection{Descriptive Statistics}

Using IBM SPSS Statistics Version 25, the study established that of the 382 respondents (household heads) in the study area; $71.5 \%$ were male (273) and $28.5 \%$ were female (109). Secondly, in terms of age groups; $24.1 \%$ of the respondents were under 35 years of age (92), 74.9\% were between 36 - 70 years (286) while only $1 \%$ were above 70 years of age (4). When it came to education, it was found that $59.9 \%$ had university degrees (229), 18.1\% had college qualifications (69), $15.4 \%$ were high school graduates (59), 5.2\% were primary school drop outs (20) and $1.3 \%$ were in the illiterate category (5). 
Regarding their sources of water and the associated cost for each, the survey confirmed that all households depended on the entire three sources; municipal, vendor and bottled water in varying proportions. For the municipal tap water, 93.7\% of the respondents confirmed their monthly water bill as being up to Kshs. 5000, 2.1\% pay above Kshs. 5000 and $4.2 \%$ as having zero bills. In addition, $93.7 \%$ stated that they spend in one month up to Kshs. 5000 on water vendor deliveries, $1.8 \%$ spend above Kshs. 5000 , while $4.5 \%$ of the respondents confirmed they do not use vended water at all. Finally, on bottled water purchase, $96.6 \%$ of the participants confirmed they use bottled water in a month and that $96 \%$ of these spend up to Kshs. 5000, some 3.4\% spend up to Kshs. 20,000. Those that do not buy bottled water (3.4\%) stated that they use other means like boiling the tap and or vendor water for drinking purposes. It should be noted that 1 USD is equivalent to Kshs. 102.57 .

\subsection{Coping BEHAVIOR}

In this section, the study used MPlus version 8.3 Demo for factor analysis. The respondents were asked to rate the efficacy of the proposed WQTS, its ability to lower water access cost, and their willingness to endorse it for installations using a five point likert scale. Additionally, the current monthly bill; municipal tap water, vendor delivered water and bottled water purchases were considered as relating to their adaptive coping behavior to water shortages. A confirmatory factor analysis in MPlus suggested that these six variables, held together well in a congeneric measurement model of adaptive coping behavior with computed Cronbach's alpha scale being equal to 0.576 [127]. The mean value for adaptive coping behavior was 3.2 (standard deviation of 1.002). On the other hand, respondents were again asked to rate using same scale, how much they agreed or disagreed with five statements relating to maladaptive behaviors as concerns the minimizing of the impact of water shortages.

Respondents with high adaptive scores tended to acknowledge the seriousness about water shortage problem in the study area. Consequently they were in agreement that the proposed solution through adoption of WQTS could make a positively difference. These enthusiasts therefore were more likely to accept the installation of the proposed provenance tracking system with 53.9\% forming the tallied majority vote from the results of the survey. Confirmatory factor analysis suggested that four maladaptive factors, fit well as a single congeneric measurement model of maladaptive coping behavior. The mean value for maladaptive behavior was 3.36 with 1.2 being the standard deviation. Responses to statements measuring adaptive and maladaptive behaviors were then run separately and formed adaptive coping score range with a mean of 3.2147 and a standard deviation of 1.00183 for the enthusiasts. On the other hand, maladaptive coping had a mean of 3.3613 and a standard deviation of 1.19946 for the pessimists.

\subsection{Extended Latent Class Results}

The study used Latent GOLD ${ }^{\circledR}$ version 5.1.0.19164 to search for the appropriate 
Latent Class structure across dimensions; the number of preference classes, with attributes of the solution being spread in four options. The indicator variables that were used ranged from coping cost to socio-demographic factors. The real meaning of this analysis was to differentiate the coping characteristics of the respondents, who despite being faced with a common water shortage problem had varied response behaviors. Two major distinct classes emerged; the enthusiasts and the pessimists (those with dogmatic tendencies). Option 2 was identified as the popular choice of the enthusiastic class while the pessimists class spread between status quo, individual coping and those with mixed (both individual and communal), see Table 1 and Table 2.

\subsection{Willingness to Pay (WTP)}

\subsubsection{Households' Preference for (WQTS)}

Although one can consider differences in marginal utilities in Table 2, one is still held back by the potential differences in scale across utility classes. Part-worths ordering or marginal WTP measurement on option with most favorable attributes is more informative. In this case, Table 3 presents the central measure of WTP is the median value of $12 \%$ monthly tariff adjustment being taken as the WTP estimate for adoption of WQTS at 53.93\% popularity.

\subsubsection{Factors Influencing the Choice of the Most Preferred Option}

It is worthy to note that of the $53.93 \%$ who prefer option 2, a total of 148 of the 206 endorsing respondents are male (71.46\%). This means that male factor was a major determinant for the adoption of WQTS in Langata. In terms of the role of other indicators, the study established that education degree was the second most influencing factor at $61.65 \%$. This means, of the 206 who prefer option 2 , each of the 127 respondents within the cluster had a university degree. In the third place was the age bracket 41 - 55 years in which 87 out of the 206 respondents who endorsed option 2 fall in. Finally, from analysis, 50 respondents from Mugumoini ward and 47 from Karen ward constituted the majority of the 206 respondents who chose option 2.

\section{Discussion}

In comparison to the current market price, the stated WTP levels indicate that the WQTS adoption will be above average at $53.93 \%$ translating to 206 endorsements from the 382 sampled respondents. This means that the estate management

Table 1. Choice options.

\begin{tabular}{cccc}
\hline OPTION & DESCRIPTION & PRICE CHANGE & TICK \\
\hline I & Households use water quality tracking individually & $15 \%$ & \\
II & Households use water quality tracking communally & $12 \%$ \\
III & Mix of I \& II & $10 \%$ \\
IV & No change & None \\
\hline
\end{tabular}


Table 2. Results from a 1 scale-2utility latent class models.

\begin{tabular}{|c|c|c|c|c|}
\hline Cluster & \multicolumn{2}{|c|}{ P-Value } & & Prices \\
\hline \multicolumn{5}{|c|}{ Utility function } \\
\hline OPTION 1 & 0.1283 & $5.1 \mathrm{e}-33$ & & $15 \%$ \\
\hline OPTION 2 & 0.5393 & $5.1 e-33$ & & $12 \%$ \\
\hline OPTION 3 & 0.3115 & $5.1 \mathrm{e}-33$ & & $10 \%$ \\
\hline \multirow[t]{2}{*}{ OPTION 4} & 0.0209 & $5.1 \mathrm{e}-33$ & & $0 \%$ \\
\hline & \multicolumn{3}{|c|}{ Predicted probability of utility class memberships } & \\
\hline \multicolumn{2}{|c|}{ Class (Gender) } & & \multicolumn{2}{|l|}{ Class 1} \\
\hline \multicolumn{2}{|c|}{ Male } & & \multicolumn{2}{|l|}{0.7147} \\
\hline \multicolumn{2}{|c|}{ Female } & & \multicolumn{2}{|l|}{0.2853} \\
\hline \multicolumn{2}{|c|}{ Total } & & \multicolumn{2}{|l|}{1} \\
\hline
\end{tabular}

Table 3. Part-worths per OPTIONS.

\begin{tabular}{ccc}
\hline OPTIONS & $\%$ & VOTES \\
\hline OPTION 4 & 2.1 & 8 \\
OPTION 2 & 53.9 & 206 \\
OPTION 3 & 31.2 & 119 \\
OPTION1 & 12.8 & 49 \\
TOTALS & 100 & 382 \\
\hline
\end{tabular}

***The options were to have average monthly household utility company water bill adjusted by $0 \%, 12 \%$, $10 \%$ and $15 \%$ for options; $4,2,3$ and 1 respectively.

committees within the study area will create a water management subcommittee. The latter will then request the Nairobi City Water \& Sewerage Company to connect the estate through a bulk meter delivering water to a central reservoir. Secondly, the individual households will close their accounts with the utility company. They will then connect through a smart meter to the estate committee-run water distribution system.

The water management subcommittee will create a water quality checking framework that largely will entail purchasing supplemental supplies for the estate central reservoir from vendors whose product quality is verifiable through the mobile phone application running on blockchain technology platform. The payment for water service from individual households will be to the estate management committee who in turn will pay Nairobi City Water \& Sewerage Company, both using a common smart system. The choice by the respondents who prefer the status quo option is insignificant; being only $2.09 \%$ of the polled votes. The existing arrangement is where each household has an individual water account with the utility company. The choice of option 2 is a very crucial arrangement because of the waste water evacuation from the households whose cost is $75 \%$ of the monthly water bill. 


\section{Conclusions}

From the objective set for this study, the majority of residents in Langata (53.9\%) have endorsed the installation of the WQTS. Secondly, it has been established that the male factor had an overriding influence over the choice decisions, which implies that most families are headed by men in this neighborhood. Additionally, the most active residents are aged 36 to 55 years of age. The result of this study is very encouraging and the analysis provides evidence for decision making. In a way, it can also be interpreted that the citizen voice here is loud enough to form basis of crowd sourcing data generation.

This form of community led water use data generation may continue only if this adopted WQTS is secured under a new water supply policy for the larger Nairobi city. With such a move, the traceability of the vendor water quality will spread to the entire Nairobi City County water distribution landscape. This is expected to bring in water access equity and promotion of groundwater environment's protection. This study recommends for a similar study to be conducted for the entire Nairobi City County to map the reaction of all the city residents towards the installation of the proposed WQTS. The paper considers that WQTS is an improved response to water shortage situation for the city in terms of coping with drought induced water shortage.

\section{Acknowledgements}

The authors are grateful to the management of the Institute for Climate Change \& Adaptation at the University of Nairobi for the supported extended during the period of research. This study received no funding supported from any organization, as such; each of the authors has no attached interest whatsoever.

\section{Conflicts of Interest}

The authors declare no conflicts of interest regarding the publication of this paper.

\section{References}

[1] Grigg, N.S. and Vlachos, E.C. (1990) Drought Water Management (Proc. Nat. Workshop, Washington DC). Colorado State University, Fort Collins.

[2] Hensher, D., Shore, N. and Train, K. (2006) Water Supply Security and Willingness to Pay to Avoid Drought Restrictions. Economic Record, 82, 56-66. https://doi.org/10.1111/j.1475-4932.2006.00293.x

[3] Hulland, K., Martin, N., Dreibelbis, R., DeBruicker, V.J. and Winch, P. (2015) What Factors Affect Sustained Adoption of Safe Water, Hygiene and Sanitation Technologies? A Systematic Review of Literature. EPPI-Centre, Social Science Research Unit, UCL Institute of Education, University College, London. https://doi.org/10.23846/SRS002

[4] UNEP (2016) A Snapshot of the World's Water Quality: Towards a Global Assessment. United Nations Environment Programme (UNEP), Nairobi, 162 p.

[5] Yang, H. and Abbaspour, K.C. (2007) Analysis of Wastewater Reuse Potential in 
Beijing. Desalination, 212, 238-250. https://doi.org/10.1016/j.desal.2006.10.012

[6] Dolnicar, S. and Schäfer, A.I. (2009) Desalinated versus Recycled Water: Public Perceptions and Profiles of the Accepters. Journal of Environmental Management, 90, 888-900. https://doi.org/10.1016/j.jenvman.2008.02.003

[7] Funamizu, N., Onitsuka, T. and Hatori, S. (2008) Water Reuse in Japan. In: Jimenez, B. and Asano, T., Eds., Water Reuse. An International Survey of Current Practice, Issues and Needs, Science and Technological Report No. 20, IWA Publishing, London, 377-386.

[8] Chakava, Y. (2013) “Transition Phase” Water Supply Interventions in Low-Income Urban Settlements: Kenya. PhD Thesis. https://dspace.lib.cranfield.ac.uk/handle/1826/8475

[9] Meybeck, M., Chapman, D. and Helmer, R. (1989) Global Freshwater Quality: A First Assessment. Blackwell Reference, Oxford.

[10] Pond, K. and Pedley, S. (2011) Current Situation in Access to Drinking Water. In: Cameron, J., Ed., Valuing Water, Valuing Livelihoods. Guidance on Social Cost Benefit Analysis of Drinking-Water Interventions, with Special Reference to Small Community Water Supplies, IWA Publishing, London, 55-74.

[11] Ojomo, E., Elliott, M., Goodyear, L., Forson, M. and Bartram, J. (2015) Sustainability and Scale-Up of Household Water Treatment and Safe Storage Practices: Enablers and Barriers to Effective Implementation. International Journal of Hygiene and Environmental Health, 218, 704-713. https://doi.org/10.1016/j.ijheh.2015.03.002

[12] Marshall, S. (2011) The Water Crisis in Kenya: Causes, Effects and Solutions. Global Majority E-Journal, 2, 31-45.

[13] Ochungo, et al. (2018) Water Supply Security in a Drought Exposed Nairobi: Adopting a Blockchain Provenance Tracking for Informal Alternatives. International Journal of Innovative Research in Science, Engineering and Technology, 7, 10475-10483.

[14] Murage, E.W. and Ndingu, A.M. (2007) Quality of Water the Slum Dwellers Use, the Case of a Kenyan Slum. Journal of Urban Health, 84, 829-838. https://doi.org/10.1007/s11524-007-9199-x

[15] Sajjadi, S.A., Alipour, V., Matlabi, M. and Biglari, H. (2016) Consumer Perception and Preference of Drinking Water Sources. Electronic Physician, 8, 3228-3233. https://doi.org/10.19082/3228

[16] Toivanen, T., Koponen, S., Kotovirta, V., Molinier, M. and Peng, C. (2013) Water Quality Analysis Using an Inexpensive Device and a Mobile Phone. Environmental Systems Research, 2, 9. https://doi.org/10.1186/2193-2697-2-9

[17] Alfonso, L. (2006) Use of Hydroinformatics Technologies for Real Time Water Quality Management and Operation of Distribution Networks. Case Study of Villavicencio, Colombia. M.Sc. Thesis, UNESCO-IHE, Delft.

[18] Ball, M., Rahman, Z., Champanis, M., Rivett, U. and Khush, R. (2013) Mobile Data Tools for Improving Information Flow in WASH: Lessons from Three Field Pilots. $1-13$.

[19] Hensher, D.A., Shore, N. and Train, K. (2005) Households' Willingness to Pay for Water Service Attributes. Environmental and Resource Economics, 32, 509-531. https://doi.org/10.1007/s10640-005-7686-7

[20] Vasquez, W.F., Mozumder, P., Hernandez-Arce, J. and Berrens, R.P. (2009) Willingness to Pay for Safe Drinking Water: Evidence from Parral Mexico. Journal of Environmental Management, 90, 3391-3400. 
https://doi.org/10.1016/j.jenvman.2009.05.009

[21] Kshetri, N. and Dholakia, N. (2002) Determinants of the Global Diffusion of B2B E-Commerce. Electronic Markets, 12, 120-129. https://doi.org/10.1080/10196780252844562

[22] Glasgow, H. (2004) Real-Time Remote Monitoring of Water Quality: A Review of Current Applications, and Advancements in Sensor, Telemetry, and Computing Technologies. Journal of Experimental Marine Biology and Ecology, 300, 409-448. https://doi.org/10.1016/j.jembe.2004.02.022

[23] Champanis, M. and Rivett, U. (2012) Reporting Water Quality: A Case Study of a Mobile Phone Application for Collecting Data in Developing Countries. Proceedings of the Fifth International Conference on Information and Communication Technologies and Development, Atlanta, 12-15 March 2012, 105-114. https://doi.org/10.1145/2160673.2160688

[24] Thomson, P., Hope, R. and Foster, T. (2012) GSM-Enabled Remote Monitoring of Rural Handpumps: A Proof-of-Concept Study. Journal of Hydroinformatics, 14, 829-839. https://doi.org/10.2166/hydro.2012.183

[25] Mukhopadhyay, S.C. (2013) Smart Sensors for Real-Time Water Quality Monitoring. Springer, Berlin. https://doi.org/10.1007/978-3-642-37006-9

[26] Lama, J.P. and Khatri, G.R. (2014) Akvo FLOW in Nepal: Real Time Monitoring of WASH Services. Sustainable Water and Sanitation Services for All in a Fast Changing World: Proceedings of the 37 th WEDC International Conference, Hanoi, Vietnam, 15-19 September 2014, 5 p.

[27] Srivastava, S., Vaddadi, S. and Sadistap, S. (2018) Smartphone-Based System for Water Quality Analysis. Applied Water Science, 8, 130. https://doi.org/10.1007/s13201-018-0780-0

[28] Pepper, I.L., Rusin, P., Quintanar, D.R., Haney, C., Josephson, K.L. and Gerba, C.P. (2004) Tracking the Concentration of Heterotrophic Plate Count Bacteria from the Source to the Consumer's Tap. International Journal of Food Microbiology, 92, 289-295. https://doi.org/10.1016/j.ijfoodmicro.2003.08.021

[29] Chaudhri, R., Sodt, R., Lieberg, K., Chilton, J., Borriello, G., Masuda, Y.J. and Cook, J. (2012) Sensors and Smartphones: Tracking Water Collection in Rural Ethiopia. Technologies for Development, Seattle. https://doi.org/10.1109/MPRV.2012.21

[30] Jonosk, et al. (2012) Mobile Phone Applications in the Water Domain. Environmental Engineering and Management Journal, 11, 919-930.

https://doi.org/10.30638/eemj.2012.116

[31] Nel, P.J.C., Booysen, M.J. and Van Der Merwe, B. (2014) ICT-Enabled Solutions for Smart Management of Water Supply in Africa. Proceeding of the 1st International Conference on the Use of Mobile ICT in Africa, Stellenbosch, 9-10 December 2014, 40-44.

[32] Hutchings, M., Dev, A., Palaniappan, M., Srinivasan, V., Ramanathan, N. and Taylor, J. (2012) mWASH: Mobile Phone Applications for the Water, Sanitation, and Hygiene Sector. Pacific Institute and Nextleaf Analytics, Oakland.

[33] Hope, R., Foster, T., Money, A. and Rouse, M. (2012) Harnessing Mobile Communications Innovations for Water Security. Global Policy, 3, 433-442.

https://doi.org/10.1111/j.1758-5899.2011.00164.x

[34] Foster, T., Hope, R., Thomas, M., Cohen, I., Krolikowski, A. and Nyaga, C. (2012) Impacts and Implications of Mobile Water Payments in East Africa. Water International, 37, 788-804. https://doi.org/10.1080/02508060.2012.738409 
[35] Fjeldsoe, B.S., Marshall, A.L. and Miller, Y.D. (2009) Behavior Change Interventions Delivered by Mobile Telephone Short-Message Service. American Journal of Preventive Medicine, 36, 165-173. https://doi.org/10.1016/j.amepre.2008.09.040

[36] Yasar, A., Khan, N.Y., Batool, A., Tabinda, A.B., Mehmood, R. and Iqbal, A. (2011) Women Perception of Water Quality and Its Impact on Health in Gangapur, Pakistan. Pakistan Journal of Nutrition, 10, 702-706.

[37] Brouwer, R., Job, F.C., van der Kroon, B. and Johnston, R. (2014) Comparing Willingness to Pay for Improved Drinking-Water Quality Using Stated Preference Methods in Rural and Urban Kenya. Applied Health Economics and Health Policy, 13, 81-94. https://doi.org/10.1007/s40258-014-0137-2

[38] Abou-Ali, H. and Carlsson, F. (2004) Evaluating the Welfare Effects of Improved Water Quality Using the Choice Experiment Method. Working Papers in Economics 131, Göteborg University, Department of Economics, Göteborg.

[39] Lemmens, R.L.G., Lungo, J., Georgiadou, P.Y. and Verplanke, J.J. (2017) Monitoring Rural Water Points in Tanzania with Mobile Phones: The Evolution of the SEMA App. ISPRS International Journal of Geo-Information, 6, 316. https://doi.org/10.3390/ijgi6100316

[40] Kumpel, E., Peletz, R., Bonham, M., Fay, A., Cock-Esteb, A. and Khush, R. (2015) When Are Mobile Phones Useful for Water Quality Data Collection? An Analysis of Data Flows and ICT Applications among Regulated Monitoring Institutions in Sub-Saharan Africa. International Journal of Environmental Research and Public Health, 12, 10846-10860. https://doi.org/10.3390/ijerph120910846

[41] Tuna, G., Arko, O. and Gulez, K. (2013) Continuous Monitoring of Water Quality Using Portable and Low-Cost Approaches. International Journal of Distributed Sensor Networks, 2013, Article ID: 249598. https://doi.org/10.1155/2013/249598

[42] Wesselink, A., Hoppe, R. and Lemmens, R. (2015) Not Just a Tool. Taking Context into Account in the Development of a Mobile App for Rural Water Supply in Tanzania. Water Alternatives, 8, 57-76.

[43] Ogallo, G. (2016) Development of Remote Water Quality Monitoring System Using Disruption Tolerant Networking (DTN). Thesis. https://etd.ohiolink.edu

[44] Adamowicz, W.L., Louviere, J. and Williams, M. (1994) Combining Stated and Revealed Preference Methods for Valuing Environmental Amenities. Journal of Environmental Economics and Management, 26, 271-292.

https://doi.org/10.1006/jeem.1994.1017

[45] Hanley, N., Wright, R.E. and Adamowicz, V. (1998) Using Choice Experiments to Value the Environment: Design Issues, Current Experience and Future Prospects. Environmental and Resource Economics, 11, 413-428. https://doi.org/10.1023/A:1008287310583

[46] Louviere, J.J., Flynn, T.N. and Carson, R.T. (2010) Discrete Choice Experiments Are Not Conjoint Analysis. Journal of Choice Modelling, 3, 57-72. https://doi.org/10.1016/S1755-5345(13)70014-9

[47] Brouwer, R. (2008) The Potential Role of Stated Preference Methods in the Water Framework Directive to Assess Disproportionate Costs. Journal of Environmental Planning and Management, 51, 597-614. https://doi.org/10.1080/09640560802207860

[48] Katayama, A., Liu, X., Musharrafiyeh, H., et al. (2009) Understanding Farmers' Preferences for Water Policy Design: An Application of Choice Experiment to Portugal-Guadiana River Basin. In: The Use of Economic Valuation in Environmental 
Policy: Providing Research Support for the Implementation of EU Water Policy under Aqua Stress, Routledge, London, New York, 47-78.

[49] Hanemann, M. (1984) Welfare Evaluations in Contingent Valuation Experiments with Discrete Response Data. American Journal of Agricultural Economics, 66, 332-341. https://doi.org/10.2307/1240800

[50] Day, B., Bateman, I.J., Carson, R.T., Dupont, D., Louviere, J.J., Morimoto, S., Scarpa, R. and Wang, P. (2012) Ordering Effects and Choice Set Awareness in Repeat-Response Stated Preference Studies. Journal of Environmental Economics and Management, 63, 73-91. https://doi.org/10.1016/j.jeem.2011.09.001

[51] Davis, K.J., Burton, M. and Kragt, M.E. (2016) Discrete Choice Models: Scale Heterogeneity and Why It Matters. Working Paper 1602, School of Agricultural and Resource Economics, University of Western Australia, Crawley.

[52] Bates, J., Fearon, J. and Black, I. (2003) Frameworks for Modeling the Variability of Journey Times on the Highway Network: A Report for UK DfT.

[53] Smith, V.K. (2006) Fifty Years of Contingent Valuation. In: Alberini, A. and Kahn, J.R., Eds., Handbook on Contingent Valuation, Edward Elgar Publishing, Cheltenham, 7-65.

[54] Genius, M., Hatzaki, E., Kouromichelaki, E.M., Kouvakis, G., Nikiforaki, S. and Tsagarakis, K.P. (2008) Evaluating Consumers' Willingness to Pay for Improved Potable Water Quality and Quantity. Water Resources Management, 22, 1825-1834. https://doi.org/10.1007/s11269-008-9255-7

[55] Kwak, S.-J. and Russell, C. (1994) Contingent Valuation in Korean Environmental Planning: A Pilot Application to the Protection of Drinking Water Quality in Seoul. Environmental and Resource Economics, 4, 511-526. https://doi.org/10.1007/BF00691926

[56] Ryan, M., Gerard, K. and Amaya-Amaya, M. (2008) Using Discrete Choice Experiments to Value Health and Health Care. Springer, Dordrecht. https://doi.org/10.1007/978-1-4020-5753-3

[57] Arrow, K., Solow, R., Portney, P., Leamer, E., Radner, R. and Schuman, H. (1998) Report of the NOAA Panel on Contingent Valuation 2003. National Oceanic and Atmospheric Administration, Damage Assessment and Restoration Program, Silver Spring.

[58] Kwak, S.-Y., Yoo, S.-H. and Kim, C.-S. (2013) Measuring the Willingness to Pay for Tap Water Quality Improvements: Results of a Contingent Valuation Survey in $\mathrm{Pu}$ san. Water, 5, 1638-1652. https://doi.org/10.3390/w5041638

[59] Cooper, J.C. (1997) Combining Actual and Contingent Behavior Data to Model Farmer Adoption of Water Quality Protection Practices. Journal of Agricultural and Resource Economics, 22, 30-43.

[60] Clark, M.D., Determann, D., Petrou, S., Moro, D. and de Bekker-Grob, E.W. (2014) Discrete Choice Experiments in Health Economics: A Review of the Literature. Pharmaco Economics, 32, 883-902. https://doi.org/10.1007/s40273-014-0170-x

[61] Lancaster, K.J. (1966) A New Approach to Consumer Theory. Journal of Political Economy, 74, 132-157. https://doi.org/10.1086/259131

[62] Tversky, A. (1972) Choice by Elimination. Journal of Mathematical Psychology, 9 , 341-367. https://doi.org/10.1016/0022-2496(72)90011-9

[63] Thurstone, L. (1927) A Law of Comparative Judgment. Psycological Review, 37, 273-286. https://doi.org/10.1037/h0070288

[64] McFadden, D. (1974) Conditional Logit Analysis of Qualitative Choice Behaviour. 
In: Frontiers in Econometrics, Academic Press, New York, 105-142.

[65] McFadden, D. (1986) The Choice Theory Approach to Market Research. Marketing Science, 5, 275-297. http://www.jstor.org/stable/184004

https://doi.org/10.1287/mksc.5.4.275

[66] Hammitt, J.K. and Herrera-Araujo, D. (2017) Peeling Back the Onion: Using Latent Class Analysis to Uncover Heterogenous Responses to Stated Preference Surveys. Journal of Environmental Economics and Management, 75, 41-53.

[67] Louviere, J.J., Flynn, T.N. and Carson, R.T. (2010) Discrete Choice Experiments Are Not Conjoint Analysis. Journal of Choice Modelling, 3, 57-72. https://doi.org/10.1016/S1755-5345(13)70014-9

[68] Hrudey, S.E. (2004) Drinking-Water Risk Management Principles for a Total Quality Management Framework. Journal of Toxicology and Environmental Health Part $A, 67,1555-1566$. https://doi.org/10.1080/15287390490491864

[69] Jalba, D.I., Cromar, N.J., Pollard, S.J.T., Charrois, J.W., Bradshaw, R. and Hrudey, S.E. (2014) Effective Drinking Water Collaborations Are Not Accidental: Interagency Relationships in the International Water Utility Sector. Science of the Total Environment, 470-471, 934-944. https://doi.org/10.1016/j.scitotenv.2013.10.046

[70] O’Flynn, B., Martinez, R., Cleary, J., Murphy, H., Regan, F., O’Mathuna, C. and Diamond, D. (2007) Smart Coast: A Wireless Sensor Network for Water Quality Monitoring. 2nd IEEE International Workshop on Practical Issues in Building Sensor Network Applications, Dublin, 15-18 October 2007, 815-816. https://doi.org/10.1109/LCN.2007.34

[71] Alkandari, A., alnasheet, M., Alabduljader, Y. and Moein, S.M. (2012) Water Monitoring System Using Wireless Sensor Network (WSN, Case Study of Kuwait Beaches). 2nd International Conference on Digital Information Processing and Communications, Lithuania, 10-12 July 2012, 709-717. https://doi.org/10.1109/ICDIPC.2012.6257270

[72] Cloete, N.A., Malekian, R. and Nair, L. (2016) Design of Smart Sensors for Real-Time Water Quality Monitoring. IEEE Access, 4, 3975-3990. https://doi.org/10.1109/ACCESS.2016.2592958

[73] Pule, M., Yahya, A. and Chuma, J. (2017) Wireless Sensor Networks: A Survey on Monitoring Water Quality. Journal of Applied Research and Technology, 15, 562-570. https://doi.org/10.1016/j.jart.2017.07.004

[74] Adu-Manu, K.S., Tapparello, C., Heinzelman, W., Katsriku, F.A. and Abdulai, J.-D. (2017) Water Quality Monitoring Using Wireless Sensor Networks: Current Trends and Future Research Directions. ACM Transactions on Sensor Networks, 13, Article No. 4. https://doi.org/10.1145/3005719

[75] Ionel, R., et al. (2015) Implementation of a GPRS Based Remote Water Quality Analysis Instrumentation. Measurement, 65, 81-93. https://doi.org/10.1016/j.measurement.2014.10.061

[76] Goodchild, M. (2007) Citizens as Sensors: The World of Volunteered Geography. GeoJournal, 69, 211-221. https://doi.org/10.1007/s10708-007-9111-y

[77] Sui, D.Z., Elwood, S. and Goodchild, M.F. (2012) Crowdsourcing Geographic Knowledge: Volunteered Geographic Information (VGI) in Theory and Practice. Springer, New York. https://doi.org/10.1007/978-94-007-4587-2

[78] Mloza-Banda, C. and Scholtz, B. (2018) Crowdsensing for Successful Water Resource Monitoring: An Analysis of Citizens' Intentions AND Motivations. Proceedings of the Annual Conference of the South African Institute of Computer 
Scientists and Information Technologists, Port Elizabeth, 26-28 September 2018, 55-64. https://doi.org/10.1145/3278681.3278688

[79] Lovett, G.M., Burns, D.A., Driscoll, C.T., Jenkins, J.C., Mitchell, M.J., Rustad, L., Haeuber, R., et al. (2007) Who Needs Environmental Monitoring? Frontiers in Ecology and the Environment, 5, 253-260. https://doi.org/10.1890/1540-9295(2007)5[253:WNEM]2.0.CO;2

[80] Cook, S., Sharma, A.K. and Gurung, T.R. (2014) Evaluation of Alternative Water Sources for Commercial Buildings: A Case Study in Brisbane, Australia. Resources, Conservation and Recycling, 89, 86-93. https://doi.org/10.1016/j.resconrec.2014.05.003

[81] Whittington, D., Lauria, D.J. and Mu, X. (1991) A Study of Water Vending and Willingness to Pay for Water in Onitsha, Nigeria. World Development, 19, 179-198. https://doi.org/10.1016/0305-750X(91)90254-F

[82] Storey, M.V., van der Gaag, B. and Burns, B.P. (2011) Advances in On-Line Drinking Water Quality Monitoring and Early Warning Systems. Water Research, 45, 741-747. https://doi.org/10.1016/j.watres.2010.08.049

[83] Steynberg, M.C. (2002) Drinking Water Quality Assessment Practices: An International Perspective. Water Science and Technology: Water Supply, 2, 43-49. https://doi.org/10.2166/ws.2002.0044

[84] Breach (2012) Drinking Water Quality Management from Catchment to Consumer. IWA, London. https://doi.org/10.2166/9781843393863

[85] Brown, D., Marsden, G. and Rivett, U. (2012) WATER Alert! Using Mobile Phones to Improve Community Perspective on Drinking Water Quality in South Africa. In: Proceedings of the Fifth International Conference on Information and Communication Technologies and Development, ACM Press, New York, 230-240. https://doi.org/10.1145/2160673.2160703

[86] Lovei, L. and Whittington, D. (1993) Rent-Extracting Behavior by Multiple Agents in the Provision of Municipal Water Supply: A Study of Jakarta, Indonesia. Water Resources Research, 29, 1965-1974. https://doi.org/10.1029/92WR02998

[87] Triche, T., Requena, S. and Kariuki, M. (2006) Engaging Private Operators in Water Supply and Sanitation Services. World Bank, Washington DC.

[88] Peletz, R., Kisiangani, J., Bonham, M., Ronoh, P., Delaire, C., Kumpel, E., Khush, R., et al. (2018) Why Do Water Quality Monitoring Programs Succeed or Fail? A Qualitative Comparative Analysis of Regulated Testing Systems in Sub-Saharan Africa. International Journal of Hygiene and Environmental Health, 221, 907-920. https://doi.org/10.1016/j.ijheh.2018.05.010

[89] Rolfe, J. and Bennett, J. (2009) The Impact of Offering Two versus Three Alternatives in Choice Modelling Experiments. Ecological Economics, 68, 1140-1148. https://doi.org/10.1016/j.ecolecon.2008.08.007

[90] Millock, K. and Nauges, C. (2010) Household Adoption of Water-Efficient Equipment: The Role of Socio-Economic Factors, Environmental Attitudes and Policy. Environmental and Resource Economics, 46, 539-565. https://doi.org/10.1007/s10640-010-9360-y

[91] Francis, M., Nagarajan, G., Sarkar, R., Mohan, V., Kang, G. and Balraj, V. (2015) Perception of Drinking Water Safety and Factors Influencing Acceptance and Sustainability of a Water Quality Intervention in Rural Southern India. BMC Public Health, 15, Article No. 731. https://doi.org/10.1186/s12889-015-1974-0

[92] Lilje, J., Kessely, H. and Mosler, H.-J. (2015) Factors Determining Water Treatment Behavior for the Prevention of Cholera in Chad. The American Journal of Tropical 
Medicine and Hygiene, 93, 57-65. https://doi.org/10.4269/ajtmh.14-0613

[93] Czajkowski, M., Giergiczny, M. and Zawojska, E. (2018) Valuing Tap Water Quality Improvements Using Stated Preference Methods: Does the Number of Discrete Choice Alternatives Matter? Agricultural and Applied Economics Association Annual Meeting, Washington DC, 5-7 August 2018.

[94] Tapsuwan, et al. (2014) Adapting to Less Water: Household Willingness to Pay for Decentralised Water Systems in Urban Australia. Water Resources Management, 28, 1111-1125. https://doi.org/10.1007/s11269-014-0543-0

[95] Latinopoulos, D. (2014) Using a Choice Experiment to Estimate the Social Benefits from Improved Water Supply Services. Journal of Integrative Environmental Sciences, 11, 187-204. https://doi.org/10.1080/1943815X.2014.942746

[96] DuBois, A.E., Crump, J.A., Keswick, B.H., Slutsker, L., Quick, R.E., Vulule, J.M. and Luby, S.P. (2010) Determinants of Use of Household-Level Water Chlorination Products in Rural Kenya, 2003-2005. International Journal of Environmental Research and Public Health, 7, 3842-3852. https://doi.org/10.3390/ijerph7103842

[97] Albert, J., Luoto, J. and Levine, D. (2010) End-User Preferences for and Performance of Competing POU Water Treatment Technologies among the Rural Poor of Kenya. Environmental Science \& Technology, 44, 4426-4432. https://doi.org/10.1021/es1000566

[98] Abou-Ali, H. and Carlsson, F. (2004) Evaluating the Welfare Effects of Improved Water Quality Using the Choice Experiment Method.

[99] Amponin, R.J., Bennagen, M., Hess, S. and Cruz, J.S. (2007) Willingness to Pay for Watershed Protection by Domestic Water Users in Tugueragaro City, Philippines.

[100] Hasler, B., Lundhede, T., Martinsen, L., Neye, S. and Schou, J.S. (2005) Valuation of Groundwater Protection versus Water Treatment in Denmark by Choice Experiments and Contingent Valuation. National Environmental Research Institute, Denmark, NERI Technical Report No. 543, 176. http://technical-reports.dmu.dk

[101] Scarpa, R. and Rose, J.M. (2008) Design Efficiency for Non-Market Valuation with Choice Modelling: How to Measure It, What to Report and Why. Australian Journal of Agricultural and Resource Economics, 52, 253-282. https://doi.org/10.1111/j.1467-8489.2007.00436.x

[102] Powe, N.A., Garrod, G.D., McMahon, P.L. and Willis, K.G. (2004) Assessing Customer Preferences for Water Supply Options Using Mixed Methodology Choice Experiments. Water Policy, 6, 427-441. https://doi.org/10.2166/wp.2004.0028

[103] Hatton MacDonald, D., Lamontagne, S. and Connor, H. (2005) The Economics of Water: Taking Full Account of First Use, Reuse and the Return to the Environment. Irrigation and Drainage, 54, S93-S102. https://doi.org/10.1002/ird.189

[104] Thacher, J., Marsee, M., Pitts, H., et al. (2011) Assessing Customer Preferences and Willingness to Pay: A Handbook for Water Utilities. Water Research Foundation, Denver.

[105] Smithers, et al. (2017) Improving Willingness-to-Pay Research in the Water Sector. ICF Consulting Limited, London. http://www.icf.com

[106] Samuelson, W. and Zeckhauser, R. (1988) Status Quo Bias in Decision Making. Journal of Risk and Uncertainty, 1, 7-59. https://doi.org/10.1007/BF00055564

[107] Meyerhoff, J. and Liebe, U. (2009) Status Quo Effect in Choice Experiments: Empirical Evidence on Attitudes and Choice Task Complexity. Land Economics, 85, 515-528. https://doi.org/10.3368/le.85.3.515

[108] Boxall, P., Adamowicz, W.L.V. and Moon, A. (2009) Complexity in Choice Experi- 
ments: Choice of the Status Quo Alternative and Implications for Welfare Measurement. Australian Journal of Agricultural and Resource Economics, 53, 503-519. https://doi.org/10.1111/j.1467-8489.2009.00469.x

[109] Lanz, B. and Provins, A. (2015) Using Discrete Choice Experiments to Regulate the Provision of Water Services: Do Status Quo Choices Reflect Preferences? Journal of Regulatory Economics, 47, 300-324. https://doi.org/10.1007/s11149-015-9272-4

[110] Hanley, N., Mourato, S. and Wright, R.E. (2001) Choice Modelling Approaches: A Superior Alternative for Environmental Valuation? Journal of Economic Surveys, 15, 435-462. https://doi.org/10.1111/1467-6419.00145

[111] Adelina, G., Jang, C. and McManus, R. (2017) Improving Drinking Quality in South Korea: A Choice Experiment. Studies in Economics 1720, School of Economics, University of Kent, Kent.

[112] Willis, K., Scarpa, R. and Acutt, M. (2005) Assessing Water Company Customer Preferences and Willingness to Pay for Service Improvements: A Stated Choice Analysis. Water Resources Research, 41, W02019. https://doi.org/10.1029/2004WR003277

[113] Birol, E. and Koundouri, P. (2008) Choice Experiments Informing Environmental Policy: A European Perspective. Edward Elgar Publishing, Cheltenham. https://doi.org/10.4337/9781848441255

[114] Blamey, R., Gordon, J. and Chapman, R. (1999) Choice Modelling: Assessing the Environmental Values of Water Supply Options. Aust J Agric Resour Econ,. 43, 337-357.

[115] Yoshida, K. (2009) Estimating Willingness to Pay for Drinking Water Quality Using Averting Expenditures and Choice Experiments. 17th Annual Conference of the European Association of Environmental and Resource Economists, Amsterdam, 24-27 June 2009.

[116] Chakava, Y., Franceys, R. and Parker, A. (2014) Private Boreholes for Nairobi's Urban Poor: The Stop-Gap or the Solution? Habitat International, 43, 108-116. https://doi.org/10.1016/j.habitatint.2014.01.012

[117] Rosato, N.S. and Baer, J.C. (2012) Latent Class Analysis: A Method for Capturing Heterogeneity. Social Work Research, 36, 61-69. https://doi.org/10.1093/swr/svs006

[118] McCutcheon, A. (1987) Latent Class Analysis. Quantitative Applications in the Social Sciences Series. Sage Publications, Newbury Park, London, and New Delhi. https://doi.org/10.4135/9781412984713

[119] Train, K. (2009) Discrete Choice Methods with Simulation. 2nd Edition, Cambridge University Press, Cambridge.

[120] Franceys, R. and Gerlach, E. (2011) Consumer Involvement in Water Service Regulation. Utilities Policy, 19, 61-70. https://doi.org/10.1016/j.jup.2010.08.003

[121] Lazarova, V., Sturny, V. and Sang, G.T. (2012) The Role of the Community Engagement towards the Success of Water Reuse in Isolated Islands and Tourist Areas. Journal of Water Reuse and Desalination, 2, 1-12. https://doi.org/10.2166/wrd.2012.057

[122] Ostrom, E. (2014) Collective Action and the Evolution of Social Norms. Journal of Natural Resources Policy Research, 6, 235-252. https://doi.org/10.1080/19390459.2014.935173

[123] Ben-Akiva, M. and Lerman, S.R. (1985) Discrete Choice Analysis: Theory and Application to Travel Demand. MIT Press, Cambridge.

[124] Allen, I.E. and Seaman, C.A. (2007) Likert Scales and Data Analyses. Quality 
Progress, 40, 64-65.

[125] Singh, A.S. and Masuku, M.B. (2014) Sampling Techniques and Determination of Sample Size in Applied Statistics Research: An Overview. International Journal of Economics, Commerce and Management, 2, 1-22.

[126] Watson, J. (2001) How to Determine a Sample Size. Penn State Cooperative Extension, University Park.

[127] Cronbach, L.J. (1951) Coefficient Alpha and the Internal Structure of Tests. Psychometrika, 16, 297-334. https://doi.org/10.1007/BF02310555 